\title{
The Factors That Have Influence on Fire Detectors Selection-room`s Height
}

\author{
RADOJE B. JEVTIĆ, School of Electrical Engineering „Nikola Tesla“, Niš Review paper \\ UDC: 614.842 .4 \\ DOI: 10.5937/tehnika1706919J
}

\begin{abstract}
Fire presents very complex process of the uncontrolled and unpredictable combustion that endangers human lives and makes material damage. That implies the influence of many different factors that fire depends on. The correct work of fire detectors also depends on those factors. One of those factors is room`s height. The simulation of fire, potential smoke detectors arrangement and smoke propagation for different room's heights were analyzed in this paper.
\end{abstract}

Key words: fire, room, height, simulation, standard

\section{INTRODUCTION}

The possibility of fire appearance in objects presents a very possible real situation that could be finished with many destructive consequences on human lives and material properties. Fire, generally defined, presents uncontrolled and unpredictable complex process of heat, smoke and flame propagation. According to the fire type (international standard ISO 7240-9 defines nine classes of fires with marks from TF1 to TF9); there are different fire products that could issue as fire consequences. They are different between themselves, related to the intensity, size and time development. For that reason, different fire detectors wouldn't react on the same way for all fires. One of the noted fires division on nine classes enables the usage propriety of some fire detectors.

For example, TF1 presents open cellulosic fire (wood); TF5 presents liquid fire (n-heptane) while TF7 presents slow smoldering (pyrolysis) wood fire etc. The results realized with those test fires should be used for testing of response time of fire detectors. For example, for heat detectors testing test fire TF6 could be used; for smoke detectors testing test fires from TF1 to TF5 could be used; for $\mathrm{CO}$ detectors testing test fires TF2, TF3 and TF9 could be used $[1,2]$.

For fire detectors selection for some concrete appliance, many factors that followed from expected fire development at the early stage, object`s geometry,

Author's address: Radoje Jevtić, School of Electrical Engineering „Nikola Tesla“, Niš, Aleksandra Medvedeva 18

e-mail: milan.jvtc@gmail.com

Paper received: 02.11.2017.

Paper accepted: 14.11.2017. ambient characteristics and potential obstruction factors, should be regarded.

Of course, the influence of noted factors could be different for the spreading of fire over the open space and inside of some objects, especially if objects have geographical, material, ambient, constructive and other specifications. The examples of the fire over the open space and in buildings are presented on figures 1 and 2 [7].

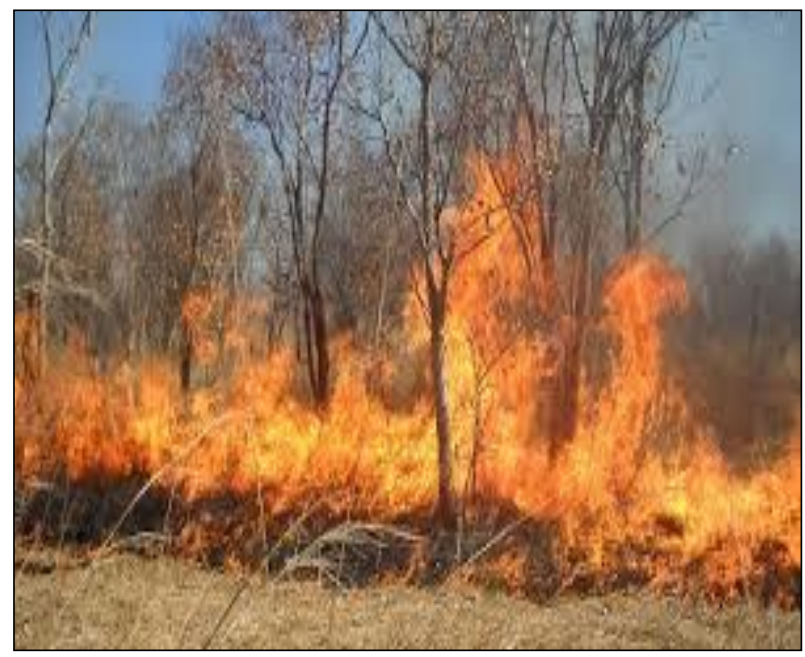

Figure 1 - The spreading of fire at the open space (figure source: http://www.vojvodinasume.rs/apelne-palite-vatru-na-otvorenom-prostoru/)

Some of factors that have influence on fire detectors selection are presented in table 1. Of course, in table 1 are presented only some of many different factors (materials that could be found in object and theirs fire properties, processes in object, object purpose and many others) that could have bigger or smaller influence on fire detectors selection. 


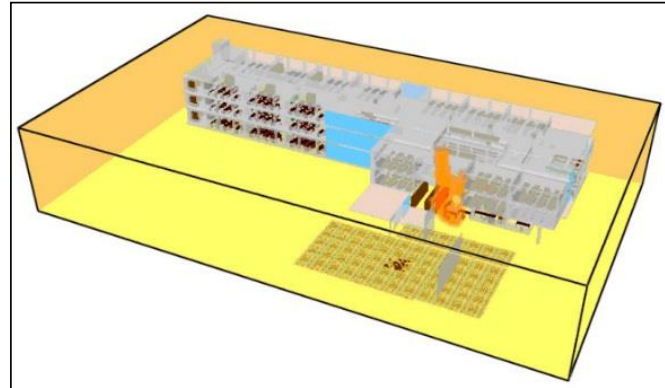

Figure 2 - The spreading of fire inside object-simulation presentation of Electro technical school "Nikola Tesla" in Niš (figure source: Jevtić, $B$. R.: The fire simulation as a safety advantage in fire prediction and fire protection)

Table 1. Factors that influences on fire detectors selection(table source: Alarm systems, M. Blagojević, 2011)

\begin{tabular}{|l|l|}
\hline Factors & Possible cases \\
\hline Possible fire type & $\begin{array}{l}\text { smoldering fire with smoke } \\
\text { development, } \\
\text { open fire without smoke } \\
\text { development, } \\
\text { open fire with particles. }\end{array}$ \\
\hline Height of the room & $\begin{array}{l}\text { limitations for fire and smoke } \\
\text { detectors }\end{array}$ \\
\hline Ambient conditions & $\begin{array}{l}\text { temperature, } \\
\text { humidity, } \\
\text { air flow... }\end{array}$ \\
\hline Obstruct factors & $\begin{array}{l}\text { smoke, } \\
\text { dust, } \\
\text { electromagnetic radiations... }\end{array}$ \\
\hline
\end{tabular}

As it can be seen, one of the very important factors for fire detectors selection is the height of the rooms in object. It is considered that this factor is the second important factor for selection, number and between distances of fire detectors, right after complete supervised area. The reason for this is in the facts that with height, temperature decreases, the smoke density decreases and intensity of flame radiation decreases. Temperature and smoke density decrement with height are presented on figures 3 and 4 [1, 5, 8].

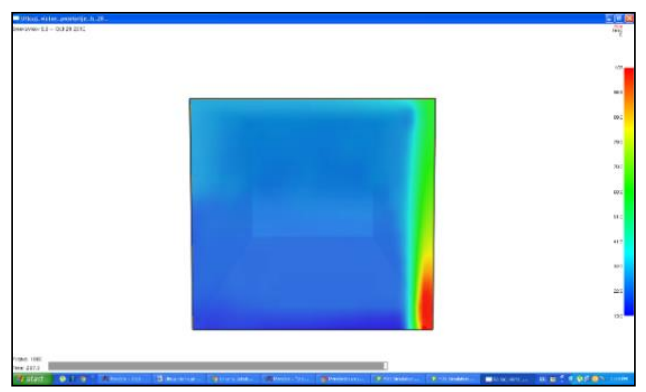

Figure 3 - Temperature decrement with height for simulation model of room with $20 \mathrm{~m}$ height (side view)

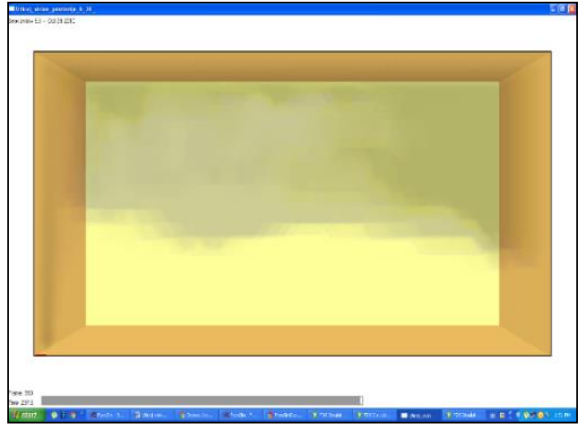

Figure 4 - Smoke density decrement with height for simulation model of room with $30 \mathrm{~m}$ height (front view)

According to all noteed, it is important to define the appropriation of usage for some fire detectors, with appropriate classes, what is presented on table 2.

Table 2. The appliance of some fire detectors types related to the room's height (table source: Alarm systems, M. Blagojević, 2011)

\begin{tabular}{|c|c|c|c|}
\hline $\begin{array}{l}\text { Room`s } \\
\text { height [m] }\end{array}$ & $\begin{array}{c}\text { Smoke } \\
\text { detectors }\end{array}$ & $\begin{array}{l}\text { Heat } \\
\text { detectors }\end{array}$ & $\begin{array}{l}\text { Flame } \\
\text { detectors }\end{array}$ \\
\hline $20-30$ & & & \\
\hline $7.5-20$ & & & \\
\hline $6-7.5$ & & & \\
\hline $4.5-6$ & & & \\
\hline up to 4.5 & & & \\
\hline
\end{tabular}

The complexity of this task in fire protection is obvious, especially if the fact that the room could have plane roof or slope roof. Related to that, there are differences between standards that deal with this problematic (BS - British Standard, NFPA - National Fire Protection Association, НПБ 88-2001 - Hoрмы пожарной безопасности,DIN VDE 0833-2 and others). Some of them are presented on tables 3 and 4.

Table 3. Limit values for room's height according to the BS - British Standard 5445 -parts 57, 58 and 59 (table source: Alarm systems, M. Blagojević, 2011)

\begin{tabular}{||l|l|l||}
\hline \multirow{2}{*}{ Fire detector type } & \multicolumn{2}{|l|}{ Roof s height } \\
\cline { 2 - 3 } & $\begin{array}{l}\text { General case } \\
{[\mathrm{m}]}\end{array}$ & Special case $[\mathrm{m}]$ \\
\hline $\begin{array}{l}\text { Heat detectors } \\
\text { The first class } \\
\text { The second class } \\
\text { The third class }\end{array}$ & 9 & 13.5 \\
\cline { 2 - 3 } & 6.5 & 12 \\
\cline { 2 - 3 } & 6 & 10.5 \\
\hline Smoke detectors & 10.5 & 15 \\
\hline Fixed heat detectors & 6 & 10.5 \\
\hline
\end{tabular}


Table 4. The usage convenience of some point fire detectors types related to the room's height related to the DIN VDE 0833-2

\begin{tabular}{|l|l|l|l|}
\hline $\begin{array}{l}\text { Room`s } \\
\text { height }\end{array}$ & $\begin{array}{l}\text { Point } \\
\text { smoke } \\
\text { setector } \\
\text { DIN } \\
\text { EN 54-7 }\end{array}$ & $\begin{array}{l}\text { Point heat } \\
\text { detectors DIN } \\
\text { EN 54-5 } \\
\text { class A1, A2, } \\
\text { B, C, D, F } \\
\text { and G, a, b }\end{array}$ & $\begin{array}{l}\text { Point flame } \\
\text { detector DIN } \\
\text { EN 54-10 } \\
\text { class 1, 2 and } \\
3\end{array}$ \\
\hline up to $45 \mathrm{~m}$ & & \\
\hline up to $20 \mathrm{~m}$ & & & \\
\hline up to $16 \mathrm{~m}$ & & \\
\hline up to12 $\mathrm{m}$ & & \\
\hline up to $9 \mathrm{~m}$ & & \\
\hline $\begin{array}{l}\text { up to } 7.5 \\
\mathrm{~m}\end{array}$ & & \\
\hline up to $6 \mathrm{~m}$ & \multicolumn{3}{|l|}{} \\
\hline & inopportune \\
\hline
\end{tabular}

The noted examples presented in tables 2, 3 and 4 are only some of proper standard`s references. The limitation of this paper doesn't allow presenting all potential cases (plane roof, slope roof, lower roof, duplicate roof and similar) defined by all proper standards. For that reason, in this paper, the cases for different room's height and proper arrangement of ionization smoke detectors were treated $[1,3,4,8]$.

\section{SIMULATION MODEL}

Simulation of fire and smoke propagation in object with smoke detectors was realized in PyroSim software, version 2012. The usage of simulation software in this and similar cases is very important from many reasons, as it was confirmed in many studies, papers and projects.

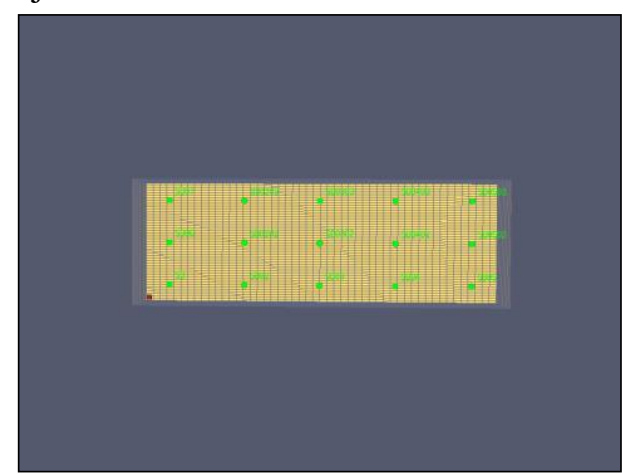

Figure 5 - Simulation model in PyroSim 2012 with smoke detectors arrangement and burner's position at the corner (above view)

The dimensions of the object's base were $60 \mathrm{~m} \mathrm{x}$ $20 \mathrm{~m}$, while the object's heights were 4.5, 6, 7.5, 20 and $30 \mathrm{~m}$. Smoke detectors arrangement was realized according to proper standard.

Burner was positioned at the corner of the object and its dimensions were $0.7 \times 0.7 \mathrm{~m}$, while the burner's heat release rates per area (HRR) were 35, 90, 650 and $1500 \mathrm{~kW} / \mathrm{m}^{2}$. Simulation model in PyroSim 2012 with smoke detectors arrangement and burner's position at the corner are presented on figures 5 (above view) and figures 6 (side view).

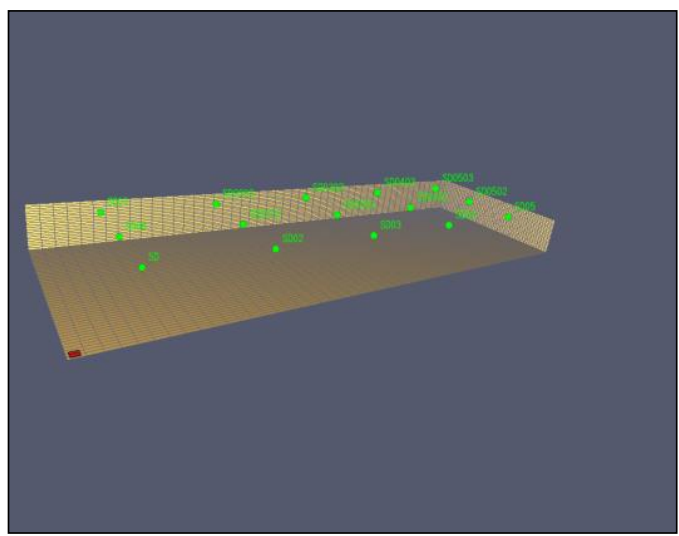

Figure 6 - Simulation model in PyroSim2012 with smoke detectors arrangement and burner's position at the corner (side view)

\section{SIMULATION RESULTS}

The simulations were realized on laptop Dell Vostro 2520, Intel Core i3-2328M CPU @ $2.20 \mathrm{GHz}$, 4GB RAM, Intel HD Graphic. The average simulation time was about 30 minutes. The simulation time was 300 seconds for every simulation. Smoke detectors were set to activate at $3,28 \%$ of obscuration. Simulation results for smoke propagation in determined time moments and reaction times of the nearest and farthest smoke detectors for some cases were presented on figures from 7 to 36 , while the complete simulation results for all room`s heights $(4.5,6,7.5,20$ and $30 \mathrm{~m})$ and all burner`s HRR $\left(35,90,650\right.$ and $\left.1500 \mathrm{~kW} / \mathrm{m}^{2}\right)$ are presented on figure $37[6,10]$.

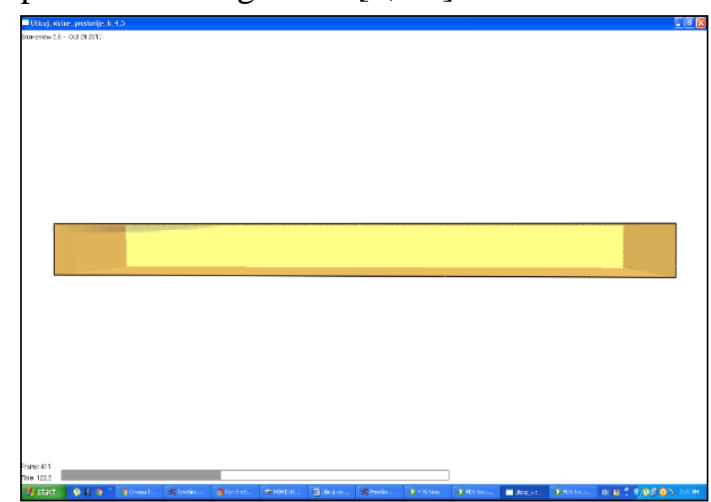

Figure 7 - Smoke propagation in simulated object for burner with HRR of $35 \mathrm{~kW} / \mathrm{m}^{2}$ and room's height of $4.5 \mathrm{~m}$ after 123.9 seconds 


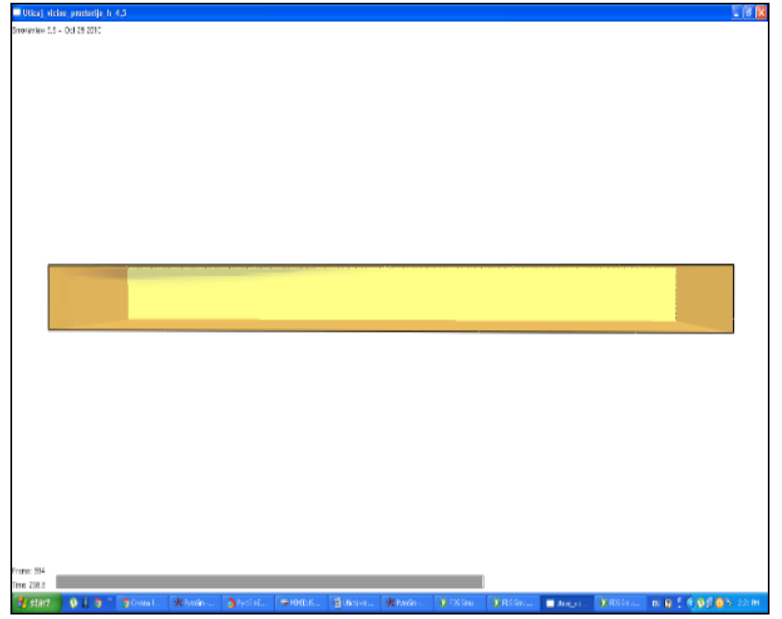

Figure 8 - Smoke propagation in simulated object for burner with HRR of $35 \mathrm{~kW} / \mathrm{m}^{2}$ and room's height of $4.5 \mathrm{~m}$ after 298.8 seconds

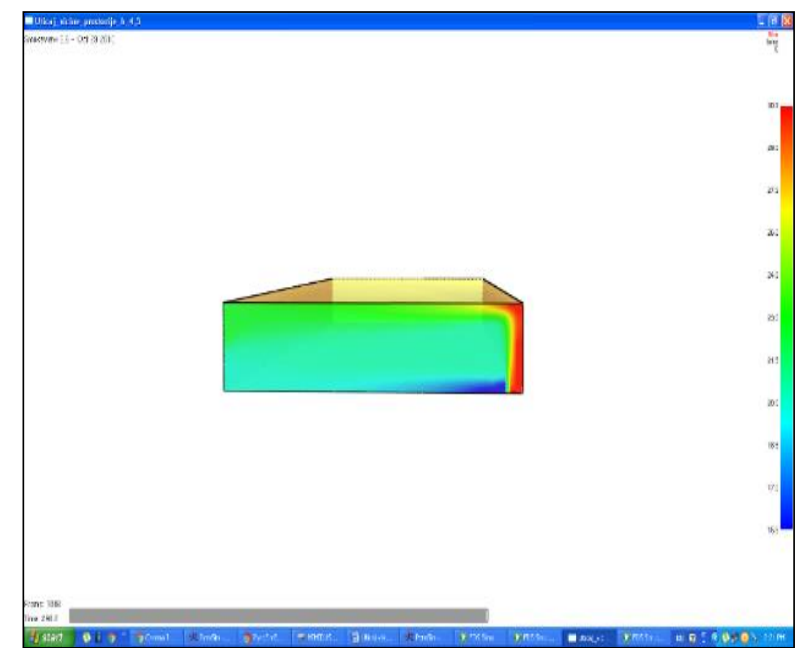

Figure 9 - Simulation results as thermal presentation for burner with HRR of $35 \mathrm{~kW} / \mathrm{m}^{2}$ and with room's height of $4.5 \mathrm{~m}$ after 298.8 seconds

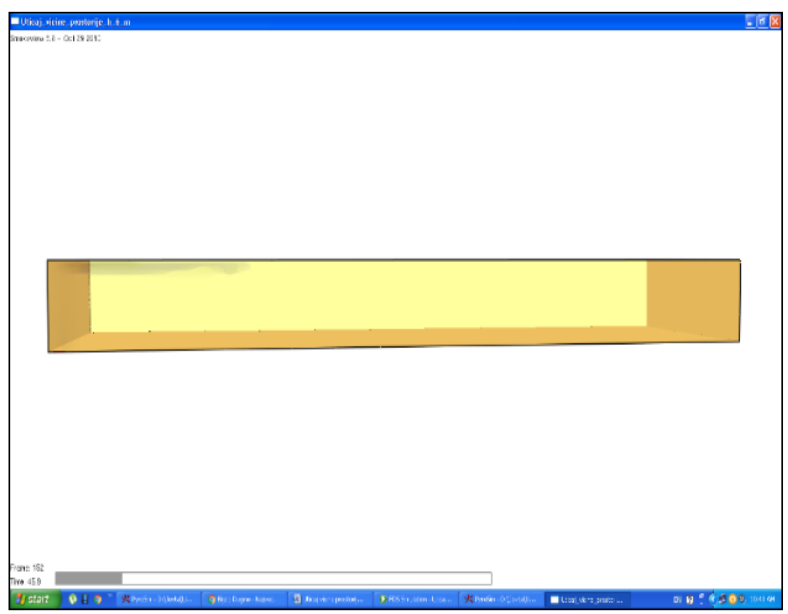

Figure 10 - Smoke propagation in simulated object for burner with HRR of $90 \mathrm{~kW} / \mathrm{m}^{2}$ and room's height of $6 m$ after 45.9 seconds

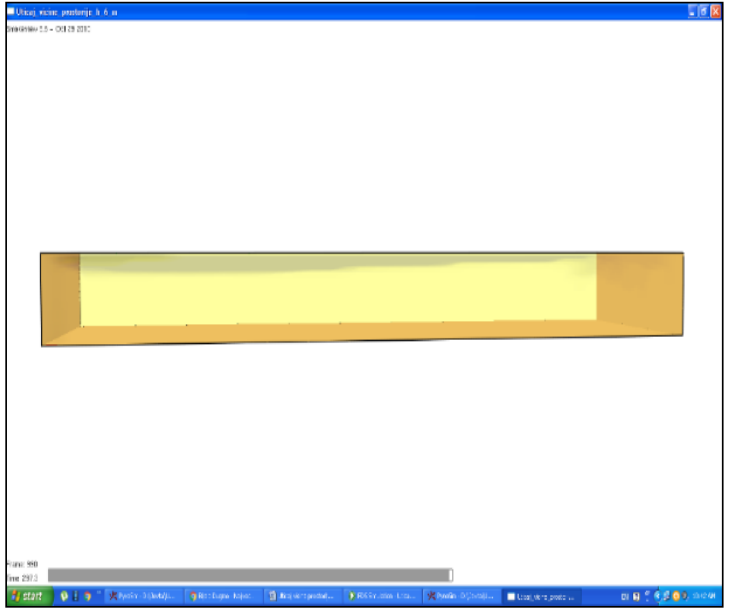

Figure 11 - Smoke propagation in simulated object for burner with HRR of $90 \mathrm{~kW} / \mathrm{m}^{2}$ and room's height of $6 \mathrm{~m}$ after 297.3 seconds

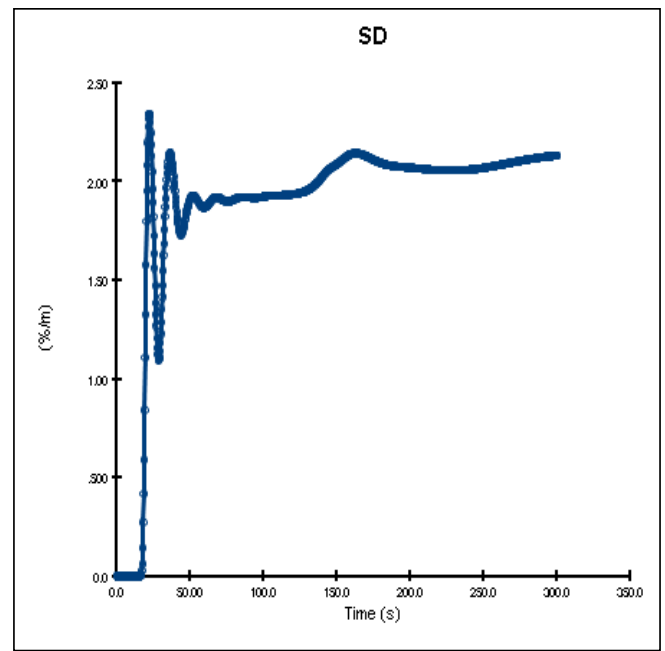

Figure 12 - Simulation results for the nearest smoke detector for burner with HRR of $90 \mathrm{~kW} / \mathrm{m}^{2}$ and with room's height of $6 \mathrm{~m}$

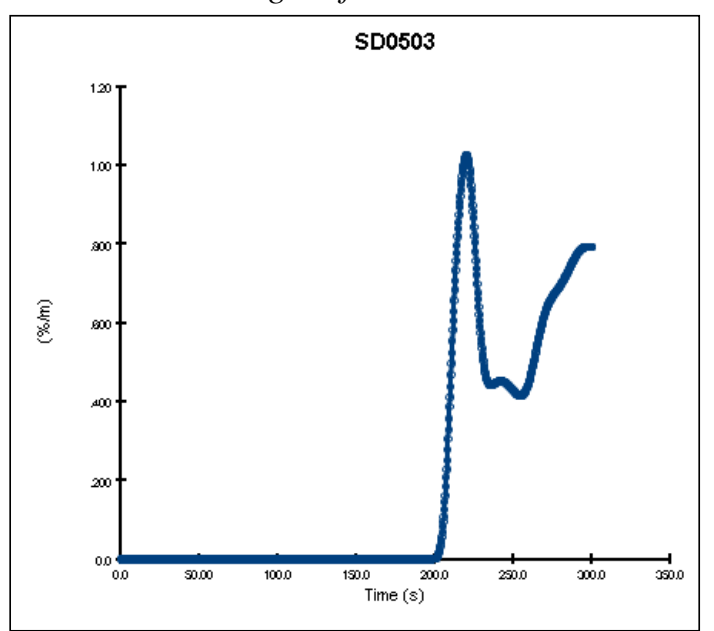

Figure 13 - Simulation results for the farthest smoke detector for burner with HRR of $90 \mathrm{kW/ \textrm {m } ^ { 2 }}$ and with room's height of $6 \mathrm{~m}$ 


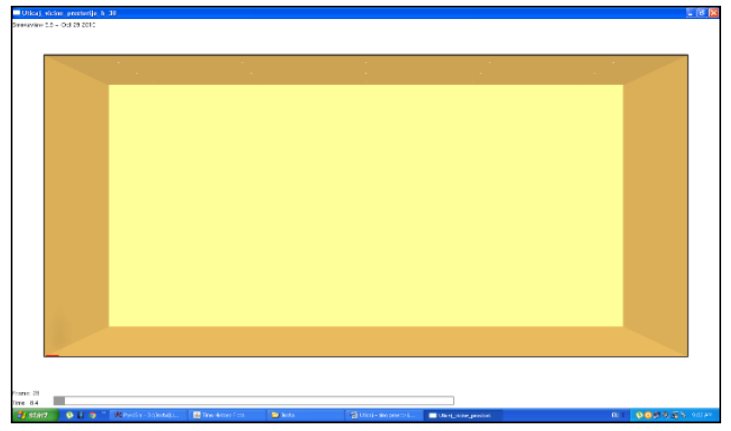

Figure 14 - Smoke propagation in simulated object for burner with HRR of $90 \mathrm{~kW} / \mathrm{m}^{2}$ and room's height of $30 \mathrm{~m}$ after 8.4 seconds

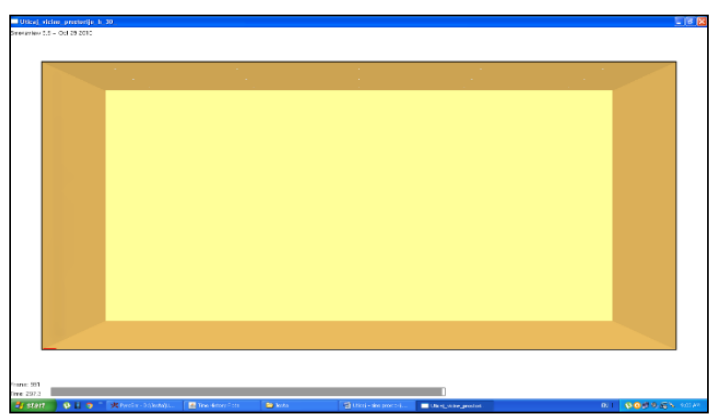

Figure 15 - Smoke propagation in simulated object for burner with HRR of $90 \mathrm{~kW} / \mathrm{m}^{2}$ and room's height of $30 \mathrm{~m}$ after 297.3 seconds

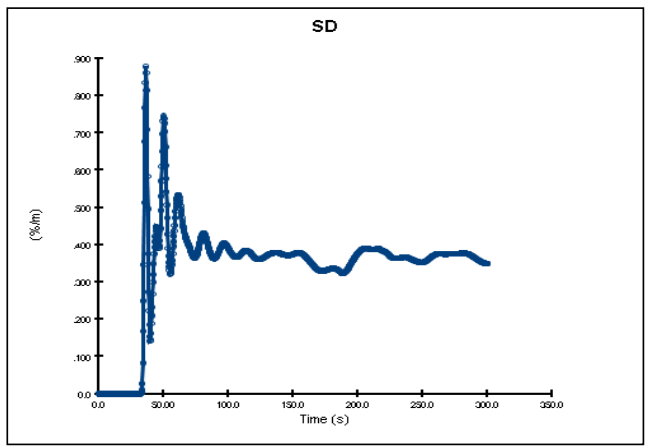

Figure 16 - Simulation results for the nearest smoke detector for burner with HRR of $90 \mathrm{~kW} / \mathrm{m}^{2}$ and with room's height of $6 \mathrm{~m}$

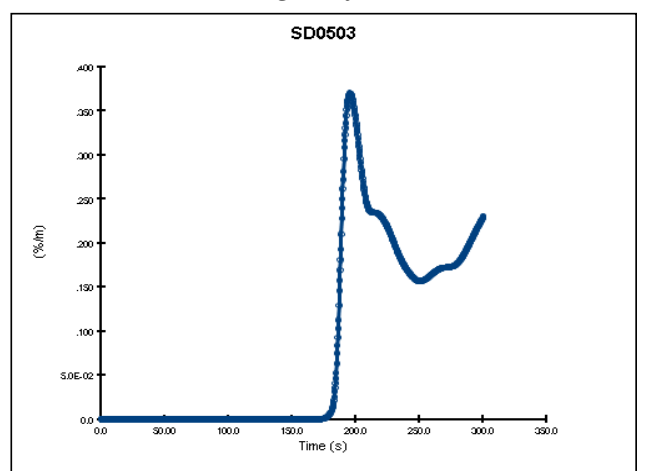

Figur 17 - Simulation results for the farthest smoke detector for burner with HRR of $90 \mathrm{~kW} / \mathrm{m}^{2}$ and with room's height of $30 \mathrm{~m}$

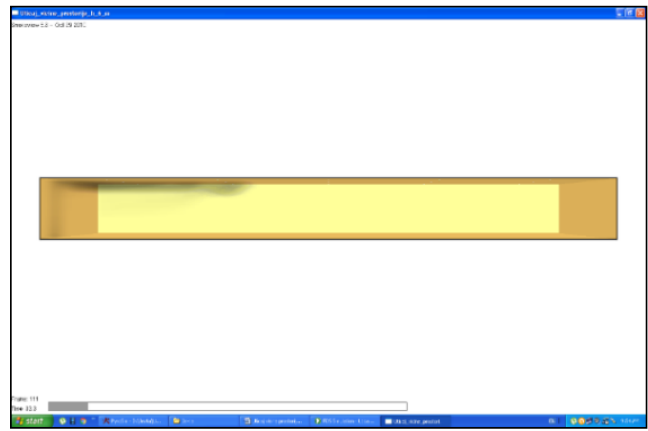

Figure 18 - Smoke propagation in simulated object for burner with HRR of $650 \mathrm{~kW} / \mathrm{m}^{2}$ and room's height of $6 \mathrm{~m}$ after 33.3 seconds

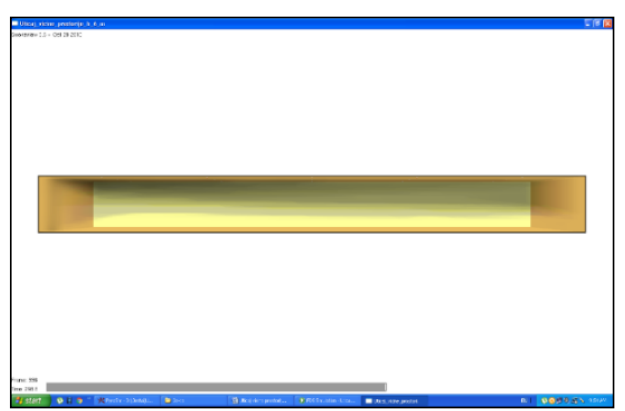

Figure 19 - Smoke propagation in simulated object for burner with HRR of $650 \mathrm{kW/ \textrm {m } ^ { 2 }}$ and room's height of $6 \mathrm{~m}$ after 298.8 seconds

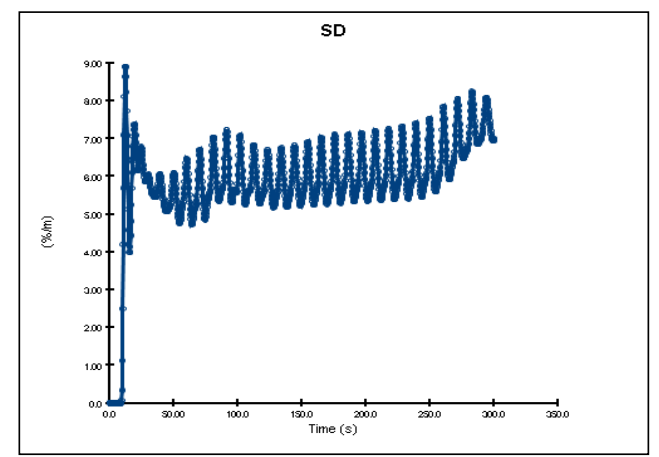

Figure 20 - Simulation results for the nearest smoke detector for burner with HRR of $650 \mathrm{~kW} / \mathrm{m}^{2}$ and with room's height of $6 \mathrm{~m}$

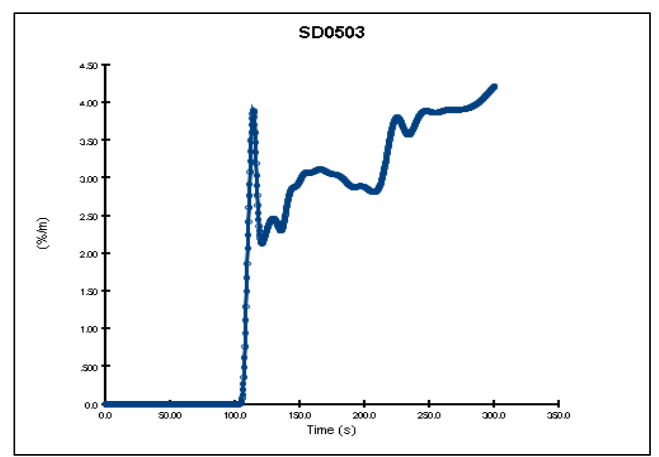

Figure 21 - Simulation results for the farthest smoke detector for burner with HRR of $650 \mathrm{~kW} / \mathrm{m}^{2}$ and with room's height of $6 \mathrm{~m}$ 


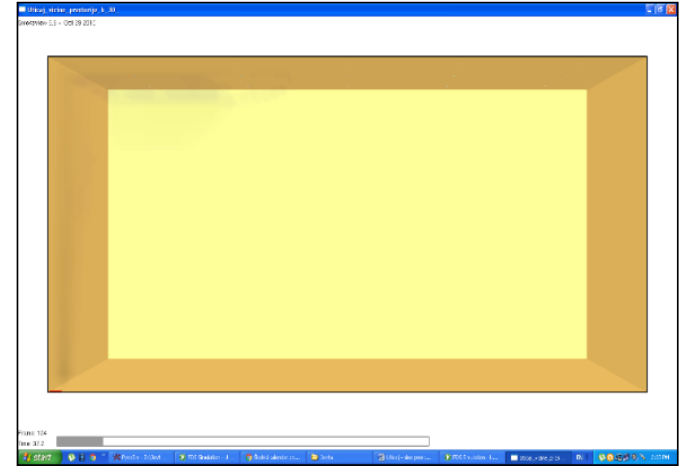

Figure 22 - Smoke propagation in simulated object for burner with HRR of $650 \mathrm{~kW} / \mathrm{m}^{2}$ and room's height of $30 \mathrm{~m}$ after 37.2 seconds

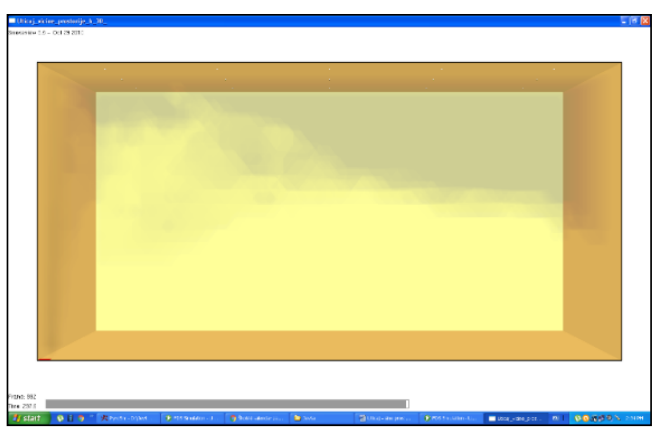

Figure 23 - Smoke propagation in simulated object for burner with HRR of $650 \mathrm{~kW} / \mathrm{m}^{2}$ and room 's height of $30 \mathrm{~m}$ after 297.5 seconds

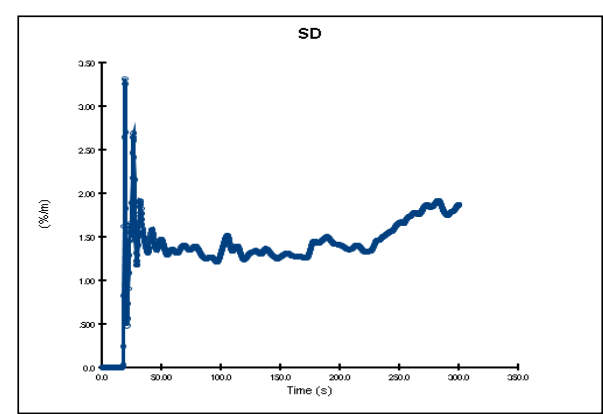

Figure 24 - Simulation results for the nearest smoke detector for burner with HRR of $650 \mathrm{~kW} / \mathrm{m}^{2}$ and with room's height of $30 \mathrm{~m}$

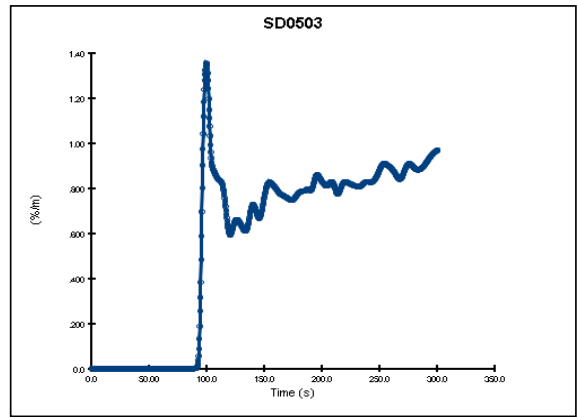

Figure 25 - Simulation results for the farthest smoke detector for burner with HRR of $650 \mathrm{~kW} / \mathrm{m}^{2}$ and with room's height of $30 \mathrm{~m}$

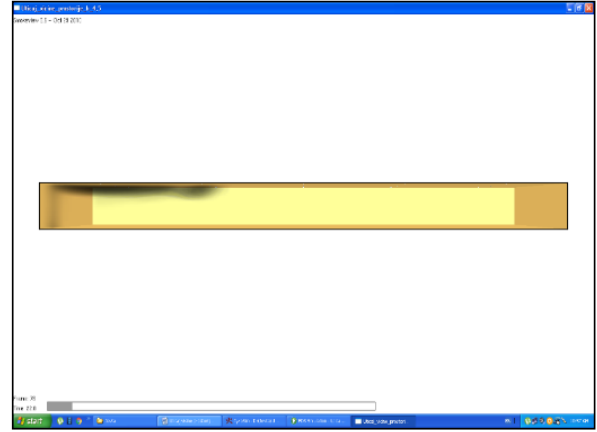

Figure 26 - Smoke propagation in simulated object for burner with HRR of $1500 \mathrm{~kW} / \mathrm{m}^{2}$ and room's height of $4.5 \mathrm{~m}$ after 22.8 seconds

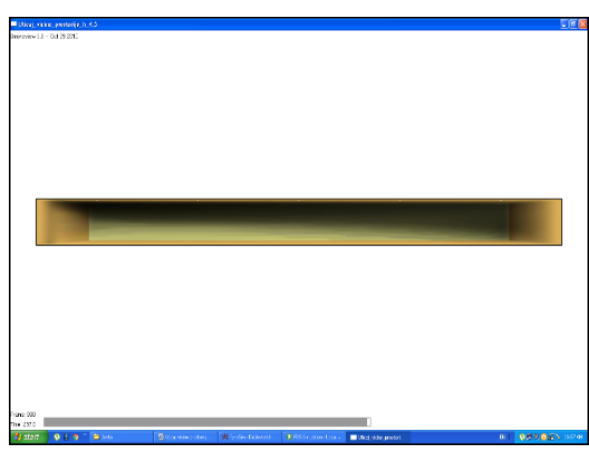

Figure 27 - Smoke propagation in simulated object for burner with HRR of $1500 \mathrm{~kW} / \mathrm{m}^{2}$ and room's height of $4.5 \mathrm{~m}$ after 297.0 seconds

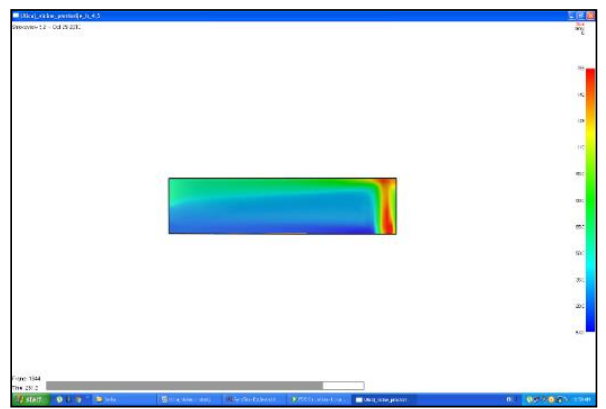

Figure 28 - Simulation results as thermal presentation for burner with HRR of $1500 \mathrm{~kW} / \mathrm{m}^{2}$ and with room 's height of $4.5 \mathrm{~m}$ after 261.3 seconds

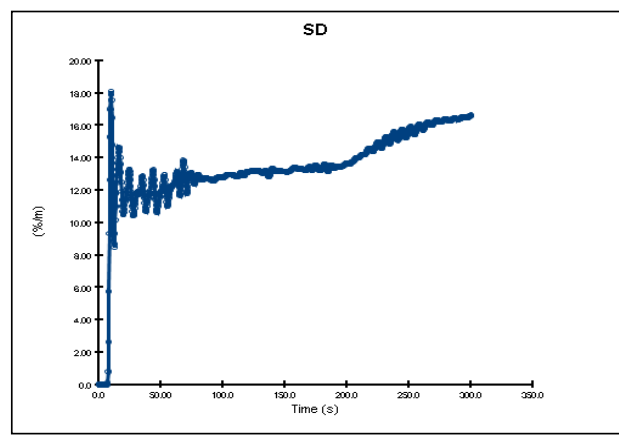

Figure 29 - Simulation results for the nearest smoke detector for burner with HRR of $1500 \mathrm{~kW} / \mathrm{m}^{2}$ and with room's height of $4.5 \mathrm{~m}$ 


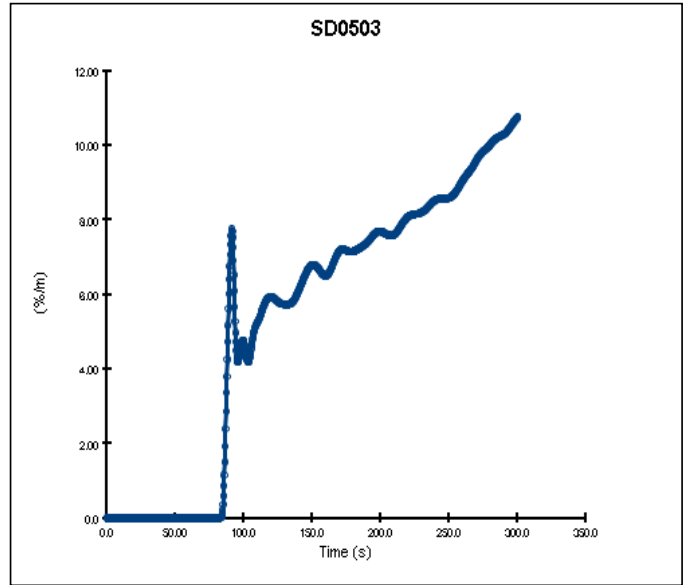

Figure 30 - Simulation results for the farthest smoke detector for burner with HRR of $1500 \mathrm{~kW} / \mathrm{m}^{2}$ and with room's height of $4.5 \mathrm{~m}$

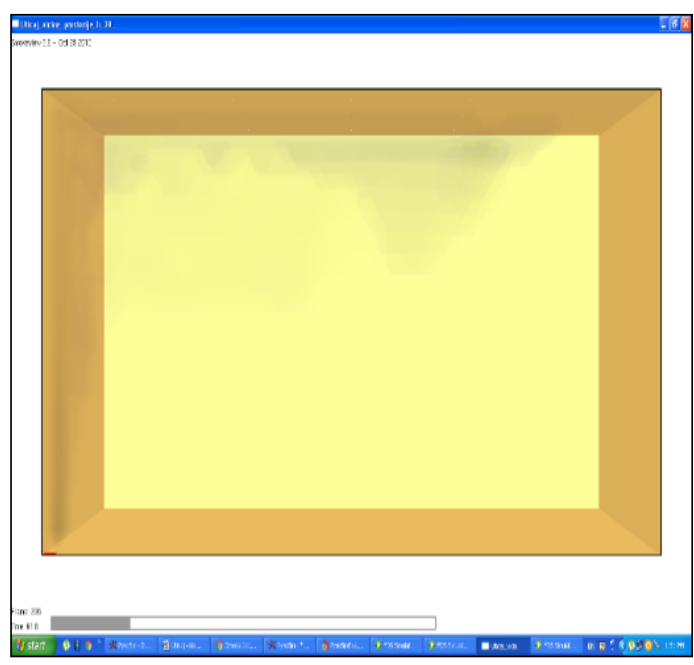

Figure 31 - Smoke propagation in simulated object for burner with HRR of $1500 \mathrm{~kW} / \mathrm{m}^{2}$ and room's height of $30 \mathrm{~m}$ after 61.8 seconds

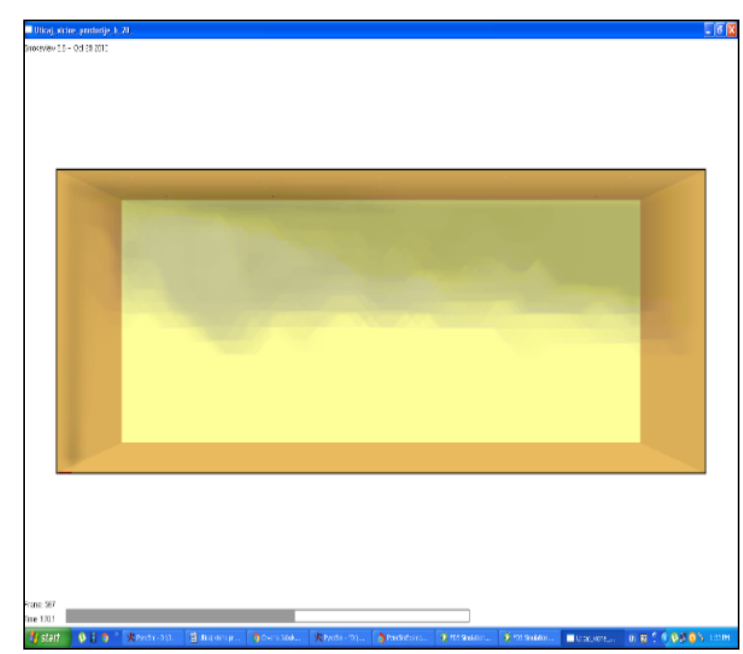

Figure 32 - Smoke propagation in simulated object for burner with HRR of $1500 \mathrm{~kW} / \mathrm{m}^{2}$ and room's height of $30 \mathrm{~m}$ after 170.5 seconds

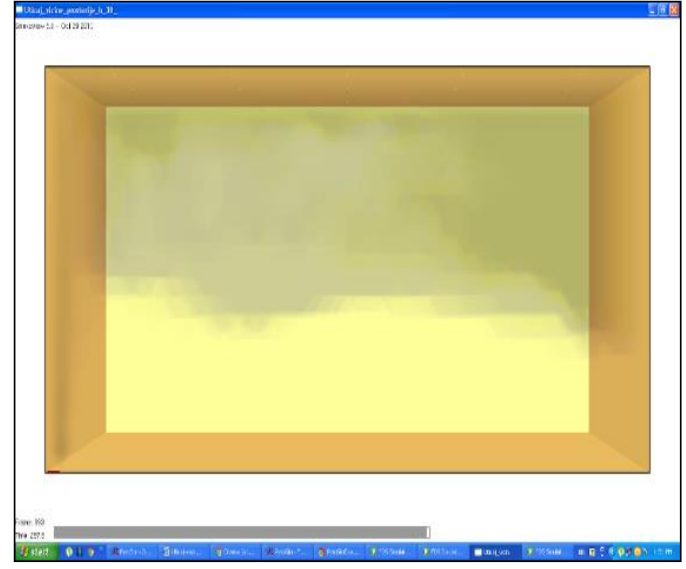

Figure 33 - Smoke propagation in simulated object for burner with HRR of $1500 \mathrm{~kW} / \mathrm{m}^{2}$ and room's height of $30 \mathrm{~m}$ after 297.9 seconds

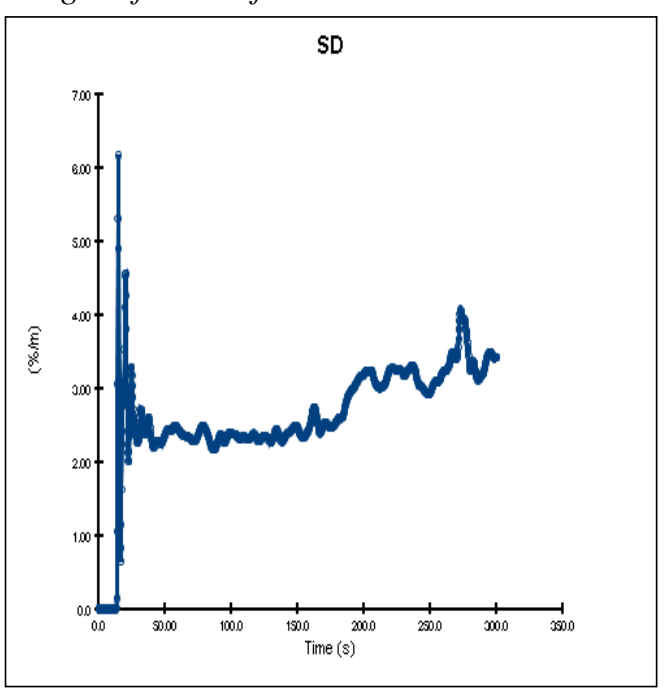

Figure 34 - Simulation results for the nearest smoke detector for burner with HRR of $1500 \mathrm{~kW} / \mathrm{m}^{2}$ and with room's height of $30 \mathrm{~m}$

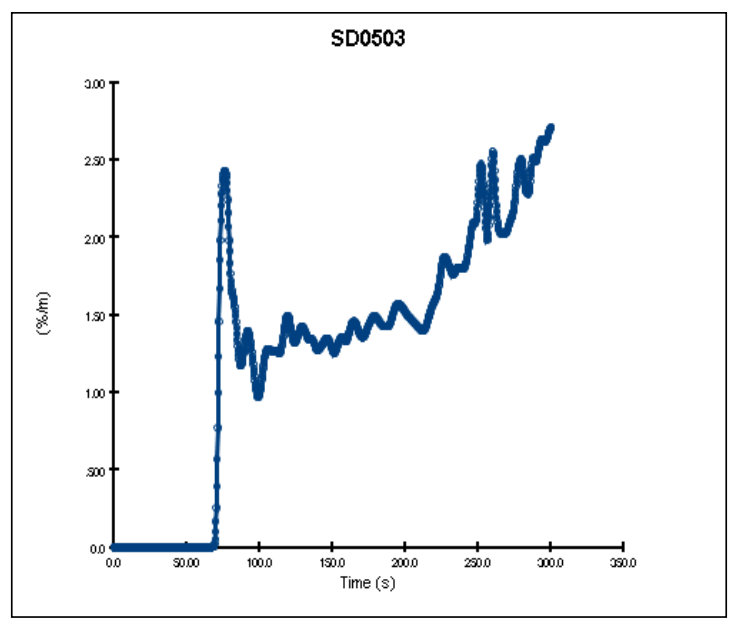

Figure 35 - Simulation results for the farthest smoke detector for burner with HRR of $1500 \mathrm{~kW} / \mathrm{m}^{2}$ and with room's height of $30 \mathrm{~m}$ 


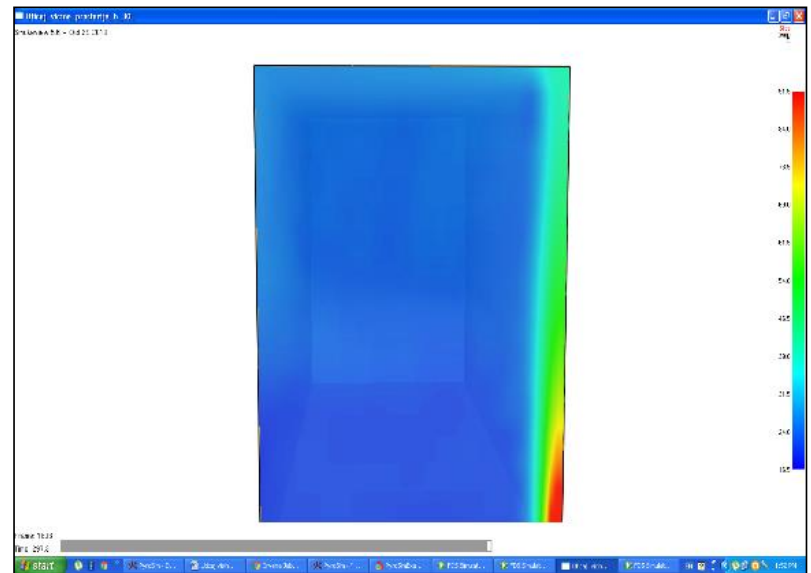

Figure 36 - Simulation results as thermal presentation for burner with HRR of $1500 \mathrm{~kW} / \mathrm{m}^{2}$ and with room's height of $30 \mathrm{~m}$ after 297.3 seconds

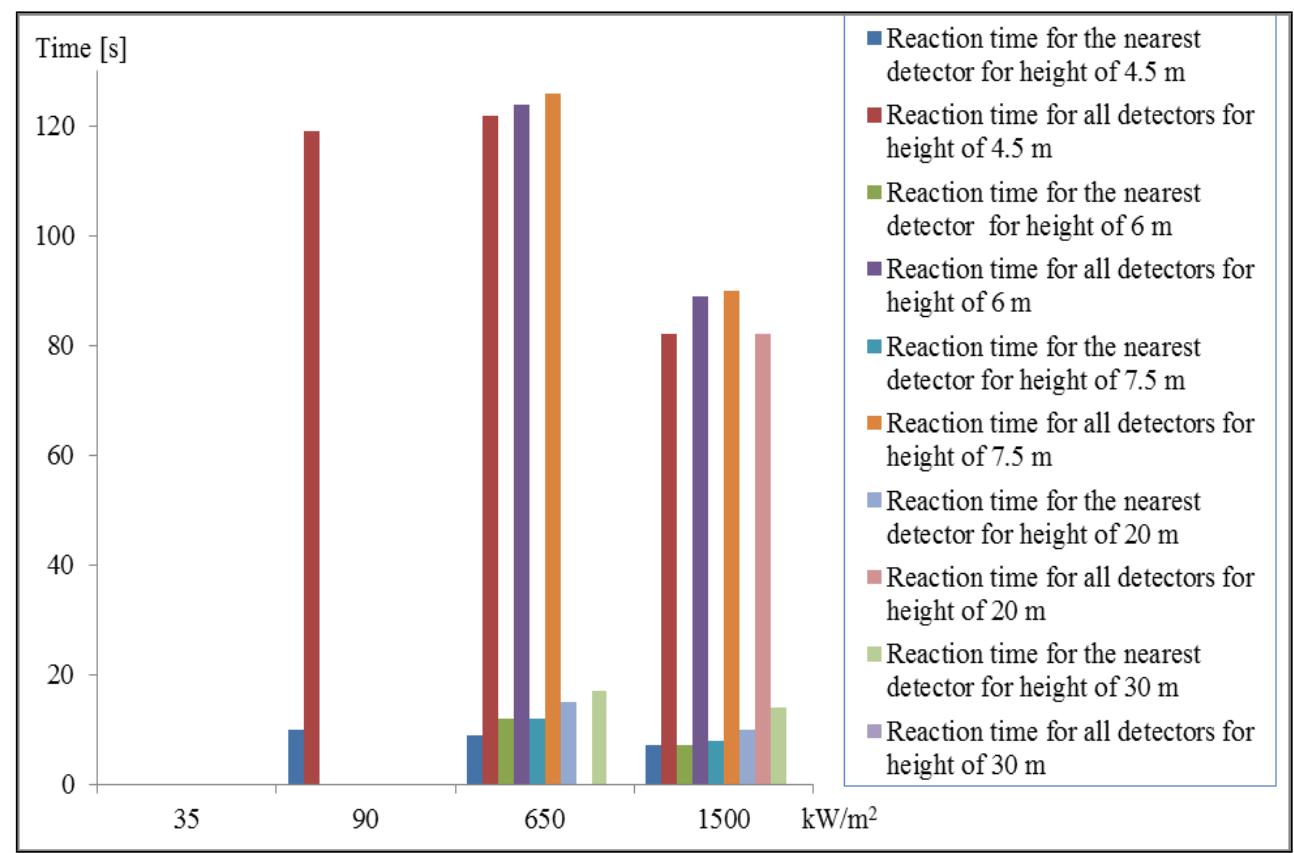

Figure 37 - The complete simulation results for all room's heights $(4.5,6,7.5,20$ and $30 \mathrm{~m})$ and all burner's $\operatorname{HRR}\left(35,90,650\right.$ and $\left.1500 \mathrm{~kW} / \mathrm{m}^{2}\right)$

\section{DISCUSSION OF REALIZED RESULTS}

Realized results for the first burner with HRR of $35 \mathrm{~kW} / \mathrm{m}^{2}$ showed that none of smoke detectors will react for every object's height from $4.5 \mathrm{~m}$ to $30 \mathrm{~m}$. It was expected because the fire of that kind was the fire with small quantity of smoke. For the second burner with HRR of $90 \mathrm{~kW} / \mathrm{m}^{2}$, smoke detectors will react only in the room with height of $4.5 \mathrm{~m}$. For the third burner with HRR of $650 \mathrm{~kW} / \mathrm{m}^{2}$, all smoke detectors will react in the room with heights of 4.5 , 6 and $7.5 \mathrm{~m}$ while for room with heights of 20 and $30 \mathrm{~m}$ all smoke detectors will not react but only some of them. For the fourth burner with HRR of 1500 $\mathrm{kW} / \mathrm{m}^{2}$, all smoke detectors will react in the room with heights of 4.5, 6, 7.5 and $20 \mathrm{~m}$ while for room with height of $30 \mathrm{~m}$ only some of them will react. Realized results confirmed facts that with height, temperature and smoke density decreased. It was obvious that according to burning material and its HRR the quantity of smoke, its density and obscuration will be different on different heights and according to that, the response of particular smoke detector will be faster or slower. It was also obvious that for rooms with heights higher than $6 \mathrm{~m}$ is very important to take care for point heat and smoke detectors arrangement especially if the fire with fast development will be expected. The installation of smoke detectors directly at the room's roof could be realized only for lower rooms. For higher rooms, smoke detectors must be installed lower from room`s roof. 
The reason for that is in the smoke's cooling and its disability to penetrate through the hot air at the top of the room. Some standards have differences also according these questions. The results realized in this paper could be used as good base for more complicated cases with different room's conditions and different detectors arrangement that could be demanded from different standards.

\section{CONCLUSION}

The situations with fire and smoke propagation in different rooms with different heights are very real and unpredictable, related to many different factors such as objects in the room, room`s purpose, the presence of different materials in the room and similar. The potential of smoke propagation simulation for different conditions is very important from many aspects, especially from safety aspect.

This kind of simulations enable fire and smoke propagation simulations without humans exposure and potential consequences on human`s health and life. Thanks to the simulation software, it is possible to choose the best detectors types with the best detectors arrangement needed for fire and smoke detection at early stage and protection of human lives and material properties [9].

\section{REFERENCES}

[1] Blagojević Đ. M, Alarm systems-added edition, Faculty of occupational safety in Niš, University in Niš, Serbia, ISBN 978-86-6093-070-7, 2015.
[2] Blagojević Đ. M, Alarm systems, Faculty of occupational safety in Niš, University in Niš, Serbia, 2011.

[3] BS 5839-6, Fire Detection and Alarm Systems for Buildings. Code of Practice for the Design and Installation of Fire Detection and Alarm Systems in Dwellings, 2004.

[4] DIN VDE 0833-2 (VDE 0833-2), 2009.

[5] Jevtić R. B,The importance of fire simulation in fire prediction, Tehnika - Kvalitet-IMS, standardizacija $i$ metrologija, No 1, pp. 153-158, ISSN 0040-2176, 2014.

[6] National Institute of Standards and Technology, Fire Dynamic Simulator Baltimore, Maryland, USA.

[7] Jevtić R. B, The influence of Air Flow Speed on Fire Propagation in Object, Arhitektura i urbanizam, Vol. 40, pp. 59-65, ISSN 0354-6055, Belgrade, Serbia, 2015.

[8] Jevtic R. B, Selection of the fire detectors and their arrangement in object, Bezbednost, UDK 343+351.74./75(05), YU ISSN 0409-2953, Vol 1/2015, pp.197-215, Belgrade, Serbia, 2015.

[9] Jevtić RB, The fire simulation as a safety advantage in fire prediction and fire protection, Safety Engineering, Vol 5., No. 1., pp. 21-28, ISSN-2217-7124, Niš, Serbia, 2015.

[10]Thunderhead Engineering, PyroSim Example Guide, 2012.

\section{REZIME}

\section{FAKTORI KOJI IMAJU UTICAJ NA RASPORED DETEKTORA POŽARA-VISINA PROSTORIJE}

Požar predstavlja veoma komplikovan proces nekontrolisanog $i$ nepredvidivog sagorevanja koji ugrožava ljudske živote i čini materijalnu štetu. To podrazumeva uticaj mnogo različitih faktora od kojih požar zavisi. Korektan rad detektora požara takođe zavisi od ovih faktora. Jedan od tih faktora je $i$ visina prostorije. Simulacija po\ara, potencijalni raspored detektora dima i rayvoj dima za različite visine prostorije su analizirani u ovom radu.

Ključne reči: požar, prostorija, visina, simulacija, standard 